\title{
The Theme of Love in Paulo Coelho's Select Novels
}

J.Punitha

Ph.D. Research Scholar

AVVM Sri Pushpam College (Autonomous).

Poondi. Thanjavur dist. Tamil Nadu, India

Dr.J.UmaSamundeeswari

Research Advisor

Assist. Professor of English

AVVM Sri Pushpam College (Autonomous).

Poondi. Thanjavur dist. Tamil Nadu, India

\begin{abstract}
Coelho's popular 'The Alchemist' is not a novel on the roles of men and women and it is not making any statement about mundane love except talking about a mystical Universal love. But it does say about love being one of the most important and valuable treasures that can be found. The other novels are equally mystical leaning much on Erosand Agape. Rather they try to show the inner lanes of agape. This is a brief attempt to show the author's experience of agape is not only universal but also personal.
\end{abstract}

Keywords: Love - Agape -Universal Love -Spiritual Love

"Love? Do you know what it means?"

-C. S. Lewis, The Great Divorce 
"Love simply is. That is the testament of Athena or Sherine or Hagia Sofia - love is. No definitions. Love and don't ask too many questions. Just love.”

\section{The Witch of Portobello -Paulo Coelho}

Nygren's magnum opus Agape and Eros (1932-1936) is from an idea that has always been present in human life which is "Love."

There are many wrong notions about Universal Love. Theological notion of Universal Love is "Agape" if it embraces a big group_like all aged people, all orphans, all elephants, etc. But it does not cover the rest of the living things and others outside that group. True love responds to all of living things. So if one has decided to limit loving to a particular category that is not the real spirit of Agape or Universal Love.Nygren called a good "love" (selfless and gratuitous) and a bad "Pagan love" (self-seeking and needful) - as Agape and Eros respectively.

But the love known to ordinary living beings, particularly human's is passionate, invested and committed. It seems to merge with the Agape inseparably as it comes into existence on a person real, more glowing and also bound by both by emotion and time perhaps.

The others in Greek philosopher's classifications like "Philia" Or Affectionate Love, "Ludus" Or Playful Love, "Pragma" Or Enduring Love, "Philautia” Or Self Love and Storge or Familiar Love are not in purview herein.

Here it is an attempt to show how Paulo Coelho merges, applies and characterize Agape and Eros in to his selected few novels, like "The Alchemist", "The Devil and Miss Prym", "By the River Piedra I Sat Down and Wept", "Eleven Minutes" and "The Witch of Portobello". 
Paulo Coelho observes of the three forms of love, Agape is total Love, the love that devours those experiences it. He even further proceeds to confirm that, whoever knows or experiences Agape sees or feels nothing else matters to them.

This is where the author seems to include the sensual love of loving human beings into Agape in his novels.

For example,in `By The River Piedra I Sat Down and Wept’: Paulo Coelho says, “We must never forget that spiritual experience is above all a practical experience of love. And with love, there are no rules."

And in Aleph, "Anyone who is in love is making love the whole time, even when they're not. When two bodies meet, it is just the cup overflowing. Love always triumphs over what we call death." He even claims it can triumph over death.

"Love is not to be found in someone else but in ourselves; we simply awaken it. But in order to do that, we need the other person." - Paulo Coelho, Eleven Minutes .Here the author refers, may be from his experiences that the love he means Agape is within our self but it is with the help of another it is quiet easy to manifest.

In the following passage he denotes by the word 'Love' -the sensual love and by the words 'dam` - agape. He looks at the sensual love as a gate, a crack to form through which the agape flows in.This is some new perception of agape.

"Love is much like a dam. if you allow a tiny crack to form through which only a trickle of water can pass, that trickle will quickly bring down the whole structure, and soon no one will be able to control the force of the current. For when those walls come down, then love takes over, and it no longer matters what is possible or impossible; it doesn't even matter whether we can keep the 
loved one at our side. To love is to lose control." Paulo Coelho, By the River Piedra I Sat Down and Wept

He confirms the flow of agape in his novel Eleven Minutes that the flow of love is a huge one like a dam break that it transcend the time limitations of ordinary sensual pleasures, a wonderful interpretation not quiet common.

"They can stay together for hours, even days. They begin the dance one day and finish it the next, or - such is the pleasure they experience - they may never finish it. No eleven minutes for them".

He elaborates further as Agape is of two types. An isolated live alone, life dedicatedonly tocontemplation, a kind of saintly life and the other diagonally opposite of it.The other one is rather engulfed in human relation and contact and particularly Enthusiasm. He dares to connote that Enthusiasm is Agape directed at some idea or something.

\section{Conclusion:}

Paulo Coelho obviously pioneers an idea of new interpretation through his novels, of Agape.Until now it is viewed as an attainment advanced spiritual practices in seclusion, but the author says it need not be so. The most common manifestation of agape is very simple and amongst us in day to day life. There are different paths to find it. Suggesting mundane love as a tool to find is not just experimental by the author but a definite happening, an assertion in all his novels invariably.he seems to swear the mundane love everyone feels in daily life is the thread of trial to be followedor treaded carefully to seek out the agape from which it oozes or seeps out. He also points out if one is sufficiently opened out soon he will be engulfed in the agape the universal love and the miracles will follow. 


\section{References}

The Alchemist -Paulo Coelho translated by Alan Clarke -2013

The Witch of Portobello (2007)_Paulo Coelho

By The River Piedra I Sat Down and Wept: : Paulo Coelho (1994)

Aleph: Paulo Coelho -translated by Margaret Jull Costa \& Zoe Perry -2011

The Pilgrimage - Paulo Coelho translated by Alan Clarke $24^{\text {th }}$ Imp-2014

Eleven Minutes : - Paulo Coelho

https://fromerostoagape.wordpress.com/2012/08/09/eros-romantic-love-and-agapeunconditional-love/

https://www.wordonfire.org/resources/article/why-you-should-read-cs-lewis-the-great-divorce http://paulocoelhoblog.com/2009/03/27/the-three-forms-of-love-eros-philos-agape-2/ 